Published July 2018

EKONOMIKAWAN : Jurnal Ilmu Ekonomi dan Studi Pembangunan

ISSN : 1693-7600 (Print), ISSN : 2598-0157 (Online), http://jurnal.umsu.ac.Id/index.php/ekawan

\title{
Analisis Pengaruh Ekspor Kopi, Tembakau, Dan Getah Karet Alam Terhadap Ekspor Di Sumatera Utara
}

\author{
Lia Nazliana Nasution ${ }^{1}$ \\ Mohammad Yusuf ${ }^{2}$ \\ Fakultas Sosial Sains, Universitas Pembangunan Panca Budi \\ Jl. Jend. Gatot Subroto Km. 4,5, Medan 20122 \\ e-mail : lianazliana@dosen.pancabudi.ac.id, yusuflangit8@gmail.com
}

\begin{abstract}
ABSTRAK
Penelitian ini bertujuan untuk mengetahui jumlah kopi yang di ekspor perusahaan di Sumatera Utara, tembakau yang dikelola perusahaan daerah maupun perusahaan swasta yang dikelola di Sumatera Utara serta mengetahui ekspor getah karet alam yang dilakukan oleh perusahaan di Sumatera Utara. Metode analisis yang digunakan adalah analisis regresi linier berganda, dengan data sekunder time series mulai dari tahun 2001 sampai dengan 2015. Adapun variabel bebas yang digunakan adalah ekspor kopi $\left(\mathrm{X}_{1}\right)$, ekspor tembakau $\left(\mathrm{X}_{2}\right)$, dan ekspor getah karet alam $\left(\mathrm{X}_{3}\right)$ sedangkan variabel terikat adalah Ekspor (Y). Hasil yang diperoleh adalah : variabel ekspor kopi berpengaruh negatif dan signifikan terhadap ekspor di Sumatera Utara, sedangkan variabel ekspor tembakau dan ekspor getah karet alam berpengaruh positif dan signifikan terhadap ekspor di Sumatera Utara.
\end{abstract}

Kata kunci : Ekspor Kopi, Tembakau, Getah Karet Alam, dan Ekspor Sumatera Utara 


\title{
Analysis of the Effect of Export of Coffee, Tobacco, and Natural Rubber latex on Exports in North Sumatra
}

\begin{abstract}
This study aims to determine the amount of coffee exported by companies in North Sumatra, tobacco managed by regional companies and private companies managed in North Sumatra and to know the export of natural rubber latex carried out by companies in North Sumatra. The analysis method used is multiple linear regression analysis, with time series secondary data starting from 2001 to 2015. The independent variables used are coffee exports (X1), tobacco exports (X2), and exports of natural rubber latex (X3) while the dependent variable is Export $(Y)$. The results obtained are: coffee export variables have a negative and significant effect on exports in North Sumatra, while the export variables of tobacco and natural rubber sap exports have a positive and significant effect on exports in North Sumatra.
\end{abstract}

Keywords: Export of Coffee, Tobacco, Natural Rubber Sap, and North Sumatra Export

\section{PENDAHULUAN}

Perdagangan internasional merupakan salah satu aspek penting dalam perekonomian setiap negara di dunia. Dengan perdagangan internasional, perekonomian akan saling terjalin dan tercipta suatu hubungan ekonomi yang saling mempengaruhi suatu negara dengan negara lain serta lalu lintas barang dan jasa akan membentuk perdagangan antar bangsa. Perdagangan internasional merupakan kegiatan yang bertujuan untuk meningkatkan kesejahteraan masyarakat suatu negara. Terjadinya perekonomian dalam negeri dan luar negari akan menciptakan suatu hubungan yang saling mempengaruhi antara satu negara dengan negara lainnya, salah satunya adalah berupa pertukaran barang dan jasa antarnegara.

Salah satu sektor perdagangan internasional adalah ekspor. Ekspor adalah suatu proses dimana barang atau komoditas dari suatu negara dikirimkan ke negara lain. Perusahaan dengan skala bisnis kecil sampai dengan menengah biasanya menggunakan proses tersebut sebagai strategi utama untuk bersaing di tingkat internasional. Kegiatan ekspor adalah sistem perdagangan dengan cara mengeluarkan barang-barang dari dalam negeri keluar negeri dengan memenuhi ketentuan yang berlaku. Ekspor merupakan total barang dan jasa yang dijual oleh sebuah negara ke Negara lain, termasuk diantara barang-barang, asuransi, dan jasa-jasa pada suatu tahun tertentu (Triyoso, 2004). 
Published July 2018

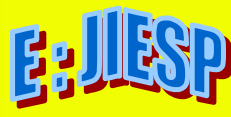

EKONOMIKAWAN : Jurnal Ilmu Ekonomi dan Studi Pembangunan

ISSN : 1693-7600 (Print), ISSN : 2598-0157 (Online), http://jurnal.umsu.ac.ld/index.php/ekawan

Kopi adalah sejenis minuman yang berasal dari proses pengolahan dan ekstraksi biji tanaman kopi. Secara umum terdapat dua jenis biji kopi, yaitu kopi arabika (Coffea arabica) dan kopi robusta (Coffea canephora) (Panggabean, 2011). Kopi merupakan salah satu minuman yang tersebar luas dan termasuk minuman yang mayoritas banyak diminum di dunia.

Tembakau juga mempunyai potensi di Indonesia, dimana tanaman tembakau diharapkan menjadi salah satu tanaman yang dapat meningkatkan kesejahteraan masyarakat. Sejauh ini tembakau dikenal dengan "emas hijau" karena nilai ekonomisnya yang tinggi. Tembakau merupakan salah satu komoditas perdagangan penting di dunia termasuk Indonesia. Produk tembakau yang utama diperdagangkan adalah daun tembakau dan rokok. Tembakau dan rokok merupakan produk bernilai tinggi, sehingga bagi beberapa negara termasuk Indonesia berperan dalam perekonomian nasional, yaitu sebagai salah satu sumber devisa, sumber penerimaan pemerintah dan pajak (cukai), sumber pendapatan petani dan lapangan kerja masyarakat (usaha tani dan pengolahan rokok).

\section{KAJIAN TEORI}

Menurut Peraturan Menteri Keuangan RI Nomor 145/PMK. 04/2007 tentang ketentuan Pabean dibidang ekspor, maka secara definisi yang dimaksud dengan ekspor adalah kegiatan mengeluarkan barang dari daerah pabean.

Menurut Lipsey dalam Komalasari (2009). Ekspor dapat diartikan sebagai total penjualanbarangyangdapat dihasilkan oleh suatu negara, kemudian diperdagangkan kepada negara lain untuk mendapatkan devisa.

Kopi merupakan salah satu jenis tanaman perkebunan yang sudah lama dibudidayakan dan memiliki nilai ekonomis yang tinggi. Konsumsi kopi dunia mencapai $70 \%$ berasal dari spesies kopi arabika dan 26\% kopi robusta. Kopi berasal dari Afrika yaitu daerah pegunungan Ethiopia. Namun, kopi sendiri baru dikenal oleh masyarakat dunia setelah tanaman tersebut dikembangkan di luar daerah asalnyayaitu Yaman di bagian selatan Arab melalui para pedagang Arab (Rahardjo P. 2012).

Di Indonesia kopi dibawa oleh Vereenigde Oost Indische Compagnie (VOC). Tanaman kopi di Indonesia mulai diproduksi di pulau Jawa dan hanya sekedar mencoba tetapi hasilnya memuaskan dan dipandang oleh VOC cukup menguntungkan sebagai komoditi perdagangan maka VOC menyebarkannya ke berbagai daerah agar para penduduk menanamnya (Najiyanti dan Danarti, 2004).

Tembakau merupakan tanaman perkebunan unggul yang mempunyai nilai ekonomis yang tinggi dan sudah lama diusahakan oleh petani tembakau di Jawa Tengah. Tanaman tembakau berperan penting bagi perekonomian Indonesia, terutama dalam penyediaan lapangan pekerjaan, sumber pendapatan bagi petani dan sumber devisa bagi negara disamping mendorong berkembangnya agribisnistembakau dan agroindustri (Cahyono,2005).

Karet alam adalah bahan polimer alam yang diperoleh dari Havea brasiliensisatau Guayule. Sejak pertama sekali proses vulkanisasi diperkenalkan pada tahun 1839, karet alam telah dimanfaatkan secara meluas pada pembuatan ban, selang, sepatu, alat rumah tangga, olah raga, peralatan militer dan kesehatan. 
Published July 2018

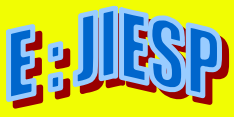

EKONOMIKAWAN : Jurnal Ilmu Ekonomi dan Studi Pembangunan

ISSN : 1693-7600 (Print), ISSN : 2598-0157 (Online), http://jurnal.umsu.ac.Id/index.php/ekawan

Karet memiliki berbagai peranan penting bagi Indonesia, antara lain :

(a) Sumber pendapatan dan lapangan kerja penduduk; (b) Sumber devisa negara dari ekspor non-migas; (c) Mendorong tumbuhnya agro-industri di bidang perkebunan; dan (d) Sumber daya hayati dan pelestarian lingkungan.

\section{METODE}

Penelitian ini menggunakan pendekatan asosiatif kuantitatif. Metode analisis yang digunakan adalah analisis regresi linier berganda dengan variabel bebas ekspor kopi $\left(\mathrm{X}_{1}\right)$, ekspor tembakau $\left(\mathrm{X}_{2}\right)$, dan ekspor getah karet alam $\left(\mathrm{X}_{3}\right)$, dan variabel terikat ekspor Sumatera Utara (Y). Data yang digunakan berjenis data sekunder mulai dari tahun 2001 sampai dengan 2015.

\section{HASIL PENELITIAN DAN PEMBAHASAN}

a. Pengaruh ekspor kopi, tembakau, getah karet alam terhadap ekspor.

Berdasarkan hasil pengujian yang telah dilakukan, diketahui bahwa variabel kopi, tembakau, getah karet alam secara bersama-sama signifikan mempengaruhi ekspor selama periode penelitian. Hal ini disebabkan karena setiap variabel yang digunakan dalam penelitian ini saling mempengaruhi satu sama lain dalam tingkat tertentu. Korelasi antar variabel dapat disebut cukup tinggi, yang selanjutnya akan berpengaruh terhadap ekspor. Pemerintah daerah dalam mengambil kebijakan pemerintah, harus selalu memperhatikan variabel kopi dan getah karet alam, karena kedua sektor ini ini sangat dominan dalam penerimaan ekspor di Sumatera Utara.

\section{b. Pengaruh negatif ekspor kopi terhadap ekspor.}

Berdasarkan hasil pengujian diketahui bahwa variabel kopi mempunyai pengaruh yang signifikan terhadap ekspor dan berkolerasi negatif. Dari pengujian di dapat nilai koefisien kopi sebesar minus 7,671. Hal ini berarti setiap 1 persen kenaikan yang terjadi pada kopi akan menurunkan jumlah ekspor 7,671 persen.

Bahwa tingkat ekspor kopi selama periode penelitian menunjukkan korelasi negatif dan signifikan terhadap ekspor. Hal ini berarti bahwa kopi memberikan nilai terhadap ekspor.

\section{c. Pengaruh positif ekspor tembakau terhadap ekspor.}

Berdasarkan hasil pengujian diketahui bahwavariabelekspor tembakaumempunyai pengaruh yang signifikan terhadap pertumbuhan ekonomi dan berkolerasi positif. Dari pengujian di dapat nilai koefisien ekspor sebesar 8,059. Hal ini berarti setiap 1 persen kenaikan yang terjadi pada ekspor tembakau akan menaikkan jumlah ekspor sebesar 8,059 persen. Bahwa ekspor tembakau selama periode penelitian menunjukkan pengaruh yang positif dan signifikan terhadap pertumbuhan ekonomi. Hal ini berarti bahwa ekspor tembakau memberikan nilai yang besar terhadap ekspor Sumatera Utara.

\section{d. Pengaruh positif ekspor getah karet alam terhadap ekspor.}

Berdasarkan hasil pengujian diketahui bahwa variabel ekspor getah karet alam mempunyai pengaruh yang signifikan terhadap ekspor dan berkolerasi positif. Dari pengujian di dapat nilai koefisien getah karet alam sebesar 6.043. Hal ini berarti setiap 1 persen kenaikan yang terjadi pada getah karet alam akan menaikkan jumlah ekspor sebesar 6,043 persen. Bahwa ekspor getah karet alam selama periode penelitian menunjukkan korelasi positif dan signifikan terhadap ekspor. Hal iniberarti ekspor getah karet alam memberikan nilai terhadap ekspor. 
Published July 2018

\section{Tabel 1}

Hasil Regresi Linear Berganda

\begin{tabular}{|c|c|c|c|c|}
\hline \multicolumn{5}{|c|}{ Dependent Variable: Y } \\
\hline \multicolumn{5}{|c|}{ Method: Least Squares } \\
\hline \multicolumn{5}{|c|}{ Date: $12 / 13 / 17$ Time: $20: 38$} \\
\hline \multicolumn{5}{|l|}{ Sample: 20012015} \\
\hline \multicolumn{5}{|c|}{ Included observations: 15} \\
\hline Variable & Coefficient & Std. Error & $\mathrm{t}-$ Statistic & Prob. \\
\hline $\mathrm{C}$ & 2160515 . & 1476335. & 1.463 .432 & 1,189583333 \\
\hline $\mathrm{X} 1$ & -7.671 .313 & 2.004 .788 & -0.382650 & 4,925694444 \\
\hline $\mathrm{X} 2$ & 8.059 .085 & 1.898 .871 & 4.244 .145 & 0.0014 \\
\hline $\mathrm{X} 3$ & 6.043 .231 & 2.490 .003 & 2.426 .998 & 0,233333333 \\
\hline R-squared & 0.884644 & \multicolumn{2}{|c|}{ Mean dependent var } & 7909346. \\
\hline Adjusted R-squared & 0.853184 & \multicolumn{2}{|c|}{ S.D. dependent var } & 1188165. \\
\hline S.E. of regression & 455264.7 & \multicolumn{2}{|c|}{ Akaike info criterion } & 2.911 .832 \\
\hline Sum squared resid & $2.28 \mathrm{E}+12$ & \multicolumn{2}{|c|}{ Schwarz criterion } & 2.930 .714 \\
\hline Log likelihood & -2.143 .874 & \multicolumn{2}{|c|}{ Hannan-Quinn criter. } & 2.911 .631 \\
\hline F-statistic & 2.811 .907 & \multicolumn{2}{|c|}{ Durbin-Watson stat } & 2.547 .669 \\
\hline Prob(F-statistic) & 0.000019 & & & \\
\hline
\end{tabular}

Sumber: Data diolah

\section{SIMPULAN}

Kesimpulan dari analisis yang telah dilakukan pada penelitian ini adalah :

Ekspor kopi mempunyai pengaruh negatif dan signifikan terhadap ekspor di Sumatera Utara. Ekspor tembakau mempunyai pengaruh positif dan signifikan terhadap ekspor di Sumatera Utara. Ekspor getah karet alam mempunyai pengaruh positif dan signifikan terhadap ekspor di Sumatera Utara.

\section{DAFTAR PUSTAKA}

Cahyono, 2005. Teknik Budi Daya Tembakau dan Analisis Usaha Tani. Kanasius, Yogyakarta.

Idrus, Muhammad, 2007. MetodePenelitianIlmu-IlmuSosial. Yogyakarta: UII.

Komalasari, Aida. 2009. Analisis Tentang Pelaksanaan Plant Layout Dalam Usaha Meningkatkan Efisiensi Produksi. Bandung : Universitas Widyatama.

Mankiw, N. Greorgy. 2007. Makroekonomi. Terjemahan oleh Fitria Liza, S.E. \& Imam Nurmawan, S.E. Edisi Keenam. Jakarta : Erlangga.

Najiyati dan Danarti, 2004. Kopi Budidaya dan Penanganan Lepas Panen. Edisi Revisi. Penebar Swadaya. Jakarta.

Panggabean, Edy.2011.BukuPintar Kopi. Jakarta Selatan: PT Agro Media Pustakahlm 124-132. 
Peraturan Menteri Keuangan RI Nomor 145/PMK. 04/2007 Tentang Ketentuan Pabean Dibidang Ekspor.

Sadono Sukirno, 2005. Mikro Ekonomi Teori Pengantar. Edisi Ketiga.PT.Rajagrafindo. Triyoso, Bambang. 2004. Analisis Kausalitas Antara Ekspor dan Pertumbuhan Ekonomi di Negara ASEAN. FE USU : Medan. 